\title{
Emplaced and Embodied Encounters: Methodological Reflections on Transcultural Research in Contexts of Italian Migration
}

Authors: Dr Georgia Wall (Independent researcher) and Dr Naomi Wells (Institute of

Modern Languages Research, School of Advanced Study, University of London)

Corresponding Author: Dr Naomi Wells

Address: Institute of Modern Languages Research, School of Advanced Study, University of London, Senate House, Malet Street, London, WC1E 7U, UK

Telephone Number: +44 (0)20 78628766

Email: Naomi.Wells@sas.ac.uk 


\begin{abstract}
This article explores the practical, ethical, and epistemological issues which arise when carrying out and sharing research in contexts of Italian migration, highlighting how greater reflexivity on our own geographic and historical location as researchers can productively inform and shape our understanding of sites of contact, exchange and confrontation in relation to contemporary Italy. Specifically, we write as researchers informed by ethnographic theories and practices, and who through our research have engaged in emplaced and embodied cultural encounters in sites which are identifiable as both transcultural and Italian.
\end{abstract}

Drawing on vignettes from research in Italy and the UK, the article highlights some of the particular contradictions, opportunities and responsibilities generated by our respective positions. We address how our positionings as white, English and female scholars located within nationally-defined Italian Studies structures have raised pertinent questions of power, privilege and voice, as we place our own biographies and bodies, themselves shaped by specific colonial, national and local histories, into critical dialogue with those on and with whom we research. Through a discussion of these 'irresolvable tensions' of our research, we seek to practically engage with the broader imperative of finding new ways of studying and writing culture.

\title{
Key Words
}

Ethnography, Reflexivity, Italian Studies, UK, Migration, Race, Transcultural

\section{Introduction}

Through a methodological attention to research itself as a form of transcultural exchange, this article illustrates how forms of reflexivity influenced by ethnographic praxis can provide unique insight both into sites of contact associated with migration to and from Italy, and into our own roles as learners, teachers and researchers in Italian Studies. Arising from a large interdisciplinary project, our reflections emerge from the questions and dilemmas that were raised in the 'emplaced and embodied' encounters of our ethnographically informed research (Puri and Castillo 2016, 1). Revisiting these encounters, we draw on recent discussions within applied linguistics regarding the role of reflexivity - that is, consideration of the circumstances of knowledge production and the researcher's role therein - in research narratives, which have illustrated how researcher vignettes can be a productive tool for critical reflection (Copland and Creese 2015; Creese, Takhi and Blackledge 2016).

In the article, we each share a vignette related to our individual research experiences, focusing on the challenges of attempting to investigate quotidian transcultural practices in sites of Italian migration. Our use of 'transcultural' is intended to highlight the complex cultural assemblages and permeations (Welsch 1999, 
197) which occur within these 'in-between' spaces of negotiation (Bhabha 2004, 2), without neglecting questions of power and cultural difference associated with more traditional 'multicultural' approaches (Guilherme and Dietz 2015, 5). Analysing each other's vignette as a way of replicating the more informal dialogues common to interdisciplinary team research, we attend to some of the particular implications and responsibilities of our gendered, national and, in particular, racialised positions. In a broader discussion of our role as UK-based academics, we highlight the importance of reflecting on the personal, local and national frameworks of reference we bring to bear on our study of Italy and Italian culture. These reflections are also aimed at contributing to contemporary debates on the need to interrogate and articulate the purpose and rationale of Italian Studies as an area of study, teaching and research. As we will illustrate, an engagement with ethnography provides an opportunity for those working in Italian Studies, and Modern Languages more widely, to reflect more explicitly on our geographic and historical locations (Puri 2016) as researchers and teachers of Italian languages and cultures.

\section{Transnationalizing Modern Languages: Ethnography and Reflexivity in Italian Studies}

The following reflections emerge from a broader interdisciplinary project which addressed how languages and cultures operate and interact across a series of exemplary cases, representative of the geographic and historic map of Italian mobility (Transnationalizing Modern Languages). Through the aim to investigate local practices in sites associated with migration to and from Italy, as researchers we became increasingly conscious of the complex ways we ourselves were embedded and implicated in these transnational and transcultural flows of Italianness. Though not explicitly foreseen in the project's original methodological framework, the interest in situated linguistic and cultural practices, alongside the desire to develop more conscious forms of researcher reflexivity, provoked our own orientation towards ethnographic forms of knowledge production.

While these ethnographically influenced approaches to reflexivity informed our own specific research in sites of Italian migration, they also respond to the aim of the project to rethink the disciplinary framework of Modern Languages (Burdett 2018). The ethical necessity of reflexive practice has long been recognised in research with more explicitly anthropological and sociological concerns (Rosaldo [1989] 1993, Back 1996). It is now also emerging in relation to supposedly more 'detached' forms of data collection and analysis, such as archival research and comparative literature, as exemplified in Puri and Castillo's recent volume on fieldwork in the Humanities (2016). From within Italian Studies, Brioni and Brioni have stressed that all research is a form of

cultural encounter, highlighting how knowledge is 'produced in and through a dialogue rather than being a "one-way relation" between the scholar and his or her "object of study" (2018, via reference to Cook 2005).

The need to pay particular attention to our own positionalities in relation to our objects of study is echoed in Derobertis' call to 'partire da me' when discussing Italian postcolonialism (2014), as well as Brioni's emphasis 
on the need for Italian literary studies to develop self-reflexive paradigms of analysis $(2015,153)$. More specifically, Bartoloni and Ricatti (2017) have engaged in similar reflexive practices on their own emotional and affective involvement as scholars and teachers of Italian Studies, through autobiographical accounts which address the contemporary idealisation of the Italian Renaissance. While we intend for this article to sit in productive dialogue with their own insights, as Italians now working in Anglophone academic contexts their biographical experiences and relationship to Italian Studies differ significantly from our own. As British-born ${ }^{1}$ teachers and researchers, whose contact with Italy arose primarily through our university education, we have found that despite this being a common trajectory for Italian Studies scholars in the UK, explicit reflections on our complex, and often critical, relationship with Italy are largely absent.

Our approach also responds to earlier calls for disciplinary renewal for Italian Studies in the UK, which highlight the need to engage with the embodied nature and highly local specificities of (research as) cultural encounter. Inviting scholars to embrace a transnational paradigm, Bond proposes the body, 'the site of lived subjectivity in motion', as an 'important hinge of meaning' through which to explore the relation between the global and the particular $(2014,422)$. Polezzi, asking how translation can disrupt European hierarchies, appeals for 'an attention to bodies and practices, to their mingling and mutual contagion' (2013). By sharing and analysing researcher vignettes reflecting on key episodes of our own experiences of researching transculturally within Italian Studies, our aim is to offer a practical example of how embodiment and locality can be inscribed in the research narrative. With the project explicitly responding to the critical juncture at which Italian and Modern Language Studies in the UK finds itself (British Academy 2009), we believe such reflexivity is vital for understanding the purpose and articulating a future for the discipline within our own context of Higher Education. Simultaneously, following Bartoloni and Ricatti's example, it is the intention that our own experiences and reflections participate in a wider dialogue with the multiplicity of historical and geographic locations from which we research and teach Italian Studies in sites across the globe.

\section{Vignettes as Research}

It is important to clarify that although an interdisciplinary team project, team members conducted their research in different and largely separate contexts, in contrast to team ethnographies where researchers observe and conduct their research together. Georgia conducted her doctoral research on food-related images of Italy in England and ethnographic methods, and developed a further postdoctoral research project focusing on Italian mobility and food-related life narratives. Naomi conducted her primary research at an intercultural centre in the city of Bologna, focusing on the cultural and linguistic practices of migrant and intercultural associations based at the centre. Despite conducting separate projects in different contexts of Italian migration, and adopting

\footnotetext{
${ }^{1}$ In other instances in the article we use 'English', rather than 'British', as the term which most accurately describes both how we were viewed by our participants ('inglese') and our own sense of linguistic (English-speaking) and national identity. We are conscious also of diverse Italian migratory trajectories to Scotland and Wales and the specific nuances these histories may lend to research.
} 
distinct theoretical and methodological frameworks, working as part of the same research team gave us the opportunity to critically reflect on our approaches and experiences together, with an emphasis on the more personal and emotional dimensions of these experiences. As Woodward highlights, informal conversations and dialogues play a vital role in interdisciplinary team research, often providing the primary forum for developing shared insights and interpretations $(2016,368)$. This article is an attempt to formalise and open up these dialogues and resulting insights by drawing on existing models influenced by ethnographic praxis, and specifically researcher vignettes.

A vignette is a way of presenting qualitative data. It is a record of the researcher's subjective ethnographic experience: a personal account of what they saw in the field, and what they thought in response. As such, vignettes are an essential tool of ethnographic research - 'without such narratives, we are probably no longer in the realm of ethnography' (Creese, Takhi and Blackledge 2016, 204). Though vignettes usually document the 'being-and-doing' of fieldwork before observations are worked into theoretical contributions, they can have multiple forms and functions. They may be used to offer a captivating introduction to research findings, as per Sennet and Cobb's sociological critique, The Hidden Injuries of Class ([1972] 1993), or data may be entirely presented in vignettes which both describe and analyse, as in Miller's The Comfort of Things (2008). They may, for example, describe a key scene (or several scenes) from the researcher's fieldwork, or they may focus on a particular character through which a certain phenomenon is made visible.

In our use of vignettes, we take the lead from Creese and Copland's discussion of the practicalities and ethics of collecting, analysing and presenting data in and as linguistic ethnography (2015), and Creese, Takhi and Blackledge's reflections on using researcher vignettes in a team ethnography (2016). Creese recounts how vignettes written by individual researchers, which describe the relationship between their background and data collection and analysis, become in themselves a valuable resource for a team project. Writing and sharing vignettes affords researchers a greater level of critical attention to their own position within the broader circumstances of knowledge production, and making them available to the reader enables 'a more dynamic, accessible and public representational strategy of both ourselves and those we observe' (Copland and Creese 2015, 70). Acknowledging critiques of the potential self-indulgence of reflexivity or of mechanical confessions, Creese, Takhi and Blackledge argue instead for a holistic reflexivity which allows space for doubt and unfamiliarity, and which is concerned with the fairness of the research process at every stage:

A reflexive research process includes not only our interpretations and analyses but how we represent ourselves and our participants, and attends to issues of accessibility, engagement, style, and voice in the accounts we write up. $(2016,205)$

By translating researcher subjectivity into the ways we textually represent our research and allowing space for the doubts and inconsistencies of our own positions, vignettes encourage reflection on the research process itself. This can be particularly productive in research which purposefully entails forms of transcultural encounter across multiple languages (Creese et al. 2015; Holmes et al. 2013). It is with this imperative in mind 
that we share and analyse researcher vignettes reflecting on key episodes of our own experiences of researching transculturally within Italian Studies.

\section{Researcher Vignettes}

Researcher Vignette 1: Georgia's vignette is based on notes she made immediately after visiting a potential research site in autumn 2017, a London café she had learned about through social media described as 'ItalianBengali'. She reports on an informal conversation with the café's owner, $A$.

'Come hai saputo che abbiamo questi biscotti?'

I guessed this was the owner, A., who had turned to address me. The other barista, the one who had been reaching for the biscuits I'd indicated, paused in his reach.

'Ho letto un articolo che parlava di qua', I replied, already wondering why the journalist had been keen to portray the 'lovingly-furnished' small shop as a real cultural melting pot; 'a meeting point for Italian Bengalis, as well as white Italians who appreciate an authentic cappuccino at the reasonable price of $£ 1.70$ '. What A. really seemed to be asking was, 'what are you doing here?'. Subsequent visits confirmed that white Italian customers were few and far between. The group of men at the bar stopped their conversation and seemed to be waiting; I felt obliged to fill the humming silence.

'Diceva che c'è il caffè buono a buon prezzo', I said truthfully.

'Il caffè non l'hai preso però', A. observed, his face creasing into a smile.

'No perchè già l'ho preso -'

'Adesso te lo offro io il caffè'.

He turned back to the coffee machine and his manner reminded me of so many other baristas, some more teasing, some even more earnest, all of them performing the same routine with distracted flair; knock out the grinds, twist in the portafilter. A. set the cup down in front of me with a gentle chink. I thought not for the first time that that marble-topped bar was like the prow of a ship and the barista a captain. The other men at the bar smiled kindly, perhaps encouragingly, one of them said 'lui è il proprietario'. It was like being in one of the village bars in Abruzzo. This was a decisively male space into which, I felt, I had been cautiously and bemusedly welcomed. A. asked me where I was from, and I answered that I was English. I asked him the same question, perhaps confusingly using the 'Lei' form. When he answered, 'siamo tutti italiani qua', I was worried that he' $\mathrm{d}$ taken my question to be some kind of challenge, that I'd assumed he wasn't Italian. At pains to clarify, I pressed (and guessed, noticing the AC Milan shield displayed on the wall), 'ma di dove? Del nord, vero?'. He told me he was from Milan, 'bellissima, Milano'. He compared London unfavourably to Milan, it was dirtier, more polluted. I asked him why he'd moved to London and he opened his palms and said, 'è finita l'Italia'. At this point the other men standing round the bar joined in with a chorus of 'è finita l'Italia, l'Italia è finita'.

In describing her initial entry into the research site, Georgia illustrates the contradictions of attempting to understand the ordinary, daily practices of the people within this space, while at the same time representing a clear interruption to the more habitual spatial order and practices of the cafe. Moving beyond positivist ideals of overcoming the long-discussed 'observer's paradox', the vignette illustrates how reflexivity on her own and others' responses to this interruption can provide rich insight into the practices associated with the space and the individuals who own or visit it. It is worth noting that Georgia mentions how her own entrance follows in the footsteps of journalists who have taken a similar interest. While often at pains to distinguish ourselves from what we may perceive as more superficial or even exploitative journalistic practices, our motivations and 
methods can often be hard to distinguish to research participants, a point on which it can be uncomfortable but productive to reflect more critically. For example, here the journalistic and academic interest in the site, as is common in so many of our selected 'case studies', appears to be provoked, at least initially, by the idea of the site and associated Italian-Bengali community as unusual or even anomalous. While our stated aim may be to highlight the ordinariness of such transcultural communities and their practices, our choice to designate them an object of study is arguably in itself exoticising and a form of methodological nationalism, reflecting how we continue to cling to the idea of discrete national cultures and communities as the norm (Wimmer and Glick Schiller 2002).

At the same time, Georgia questions the journalist's coherent narrative of the café as a 'cultural melting pot' and meeting point for 'Italian-Bengalis' and 'white Italians', which stands at odds with her own experiences in the site. Despite existing as a community formed within transcultural and transnational flows between Italy, Bangladesh and the UK, this does not necessarily translate into more fluid community boundaries. It is thus important not to conflate Georgia's recognition of shared embodied and habitual practices associated with Italianness in A.'s preparation of the coffee, with ideals of collapsed racial and national boundaries. Georgia potentially points here to uncritically positive representations of multiculturalism, which paper over the asymmetrical power relations of which transcultural practices are a product rather than solution, as foregrounded in Pratt's definition of the 'contact zone' in which 'cultures meet, clash and grapple with each other' $(1991,34)$. It is not possible to conclude from the short vignette whether the absence of white Italians is connected to racial or other forms of discrimination or separation, or the understandable desire to sustain communal relations built around a shared Italian-Bengali identity and experiences, or most likely both. Nevertheless, Georgia's reflection is a reminder that the study of transcultural practices cannot at the same time ignore the continued power and significance of community boundaries.

Georgia also underlines the gendered nature of the space, pointing to the complex ways her gender, race and nationality intersect, leaving uncertainties as to the precise meanings each attribute conveys. As she mentions, entering a male-dominated bar in Abruzzo would likely provoke a similar sense of being out of place. The fact that she is greeted here with a mostly cheerful bemusement may nevertheless point to privileges afforded to a young white woman, a position which can permit access to spaces even where one is clearly out of place (Gellner 2012, 119-120). There are other aspects of Georgia's identity, such as class, or other non-verbal aspects of communication, not foregrounded here but which inevitably also influenced how she was received within this space. As Mullings argues, this illustrates the impossibility of achieving an entirely transparent reflexivity, given the multiplicity of potential 'meanings attached to a researcher's body, regardless of the way that he/she may choose to represent it' $(1999,344)$. Despite this uncertainty, the stilted dialogue between Georgia and A. speaks to differences which appear, at least at this early point, to be an obstacle to the creation of what Mullings describes as shared positional spaces, where 'the situated knowledges of both parties [...] engender a level of trust and co-operation' $(1999,340)$. Georgia initially aims to create such a space by drawing 
on her enjoyment of Italian coffee as a possible point of affinity but A. appears aware, particularly after previous visits by journalists, that her curiosity goes beyond the search for a good cappuccino.

Racial differences come to the fore as Georgia stumbles over the choice between the lei or tu forms, with the tu form feeling more appropriate in the informal café environment but avoided perhaps due to her awareness of the racially loaded use of the tu form in Italy as a sign of intentional disrespect to black Italians and migrantorigin citizens (Faloppa 2011, 8). While as learners of Italian we are taught in our grammar classes straightforward distinctions between formal/informal contexts, or clear differences in status or age, these fail to prepare us for the more complex social environments and relationships which we encounter outside of the classroom. Questions of race are further highlighted with the seemingly straightforward question 'where are you from?'. Again, as learners of Italian, the phrase 'Di dove sei?' may take us back to neutral conversation starters taught in the early years of our Italian classes. But we are reminded here, following Bakhtin, of the social and heteroglossic nature of language, with every utterance bearing the sediments or traces of its other past uses (1981). Echoes of these past uses give these seemingly neutral words a heavy racial charge, reminding the listener as it does of an often-heard challenge to a (non-white) individual's sense of national belonging, with the here unintended but implied and often secondary question of 'but where are you really from?' Even though Georgia's question follows A.'s own same question, her whiteness connects her to these past uses and highlights how words and expressions are not understood in isolation from the racial attributes of the speaker and the associated histories of racialisation.

Recognising this perceived challenge, Georgia attempts to repair the situation by focusing on A.'s local affiliations, illustrating how a focus on the local, particularly in relation to urban environments, does seem to allow for less racially charged and exclusivist discussions of identity. A.'s continued powerful affective attachment to Milan and Italy are accompanied by a more critical assessment of its current state, as echoed by other customers at the bar. These seemingly contradictory feelings are part and parcel of many of our experiences of national belonging, but would appear to be heightened in a migration context where departure is forced largely by circumstances rather than desire.

Researcher Vignette 2: This vignette is drawn from a series of encounters during Naomi's fieldwork which took place in autumn 2014 at a self-described Intercultural Centre used by a number of migrant and intercultural associations in the city of Bologna.

'In Inghilterra molte ragazze portano il velo, vero?' asked an Italian-Egyptian teenager with envy, and I leapt on the opportunity to create an at least partial sense of solidarity, confirming the commonplace nature, particularly in my home city of Birmingham, of what in contrast continued to be a highly visible mark of difference in Italy, even in the seemingly more 'progressive' Bologna. Similar conversations occurred again and again, for example in an interview with the young leaders of a Peruvian association, one of whom had also spent some time living in London. Discussing the challenge of opening a Peruvian restaurant in the apparently closed and traditional Bolognese food 
market, the conversation quickly turned, through a seemingly mutual interest, to discussing how much more diverse and open the UK market was to Peruvian food and restaurants. While benefiting from this opportunity to create a shared solidarity based on my own partial 'outsider' relationship to Italy, this example was particularly ironic given my own parallel seeking out of the 'authentic' traditional Bolognese delicacies in my previous visits to the city. Or in a conversation discussing community language teaching in Bologna, the comment that 'penso che da voi la situazione sia più avanzata', even if I had to admit I didn't know much about my own context until this comment encouraged me to later read up on the subject of community language schools in Birmingham and the UK. And a repeated point of comment and discussion, again at both others and my own prompting, was on the most striking distinction between Italy and the UK, relating to the conspicuous absence of black and Asian people from positions of authority which was an undeniably marked difference from my own lived experience in Birmingham.

This is not to suggest that racial inequalities, xenophobia and racism are by any means resolved issues in Birmingham or the UK, and also as a white British-born woman, who repeatedly 'passed' visually as Italian, it was evident to those I met that I had no similar personal experiences of racial or xenophobic discrimination in either the UK or Italy. Nevertheless, coming from the UK was undeniably an aspect of my identity I drew upon to build solidarity with migrant citizens and related activists in Bologna, with my incidental city of birth and upbringing giving me a form of associated 'multicultural' credentials, and perhaps even authority, on the subject.

Naomi's vignette addresses positionality; her position in relation to her research participants and its influence on research processes and findings. Her Englishness, and her home city of Birmingham, are presented as facilitators of the shared positional space Georgia reveals struggling to create in her vignette. Framing her “"multicultural" credentials' in terms of opportunity, she makes evident the element of performance in participant interviews on the part of both the interviewer and the interviewee (Heller 2009, 255-6), highlighting here how she as interviewer plays on different aspects of her subjectivity across multiple dialogues. She indicates how she actively and repeatedly drew on not only the sense of solidarity these 'credentials' generate with participants, but also the potential 'authority' they granted her. Her affective ties with her home city, her lived experience and the frustrations she shares with her research participants, all bring to the fore a tension that exists between our ethnographic impulse to refrain from generalising judgements, and the instinct and responsibility to query what we would, in other circumstances, call out or criticise. This is an issue which is particularly relevant when we take into account our position as UK-based researchers of Italian Studies and the colonial and national histories which have shaped Italy, the UK, and the relationship between the two, as we discuss below.

It is worth noting that Naomi's account bespeaks a certain hesitancy. Her language as a whole indicates doubt; she suggests that interests are 'seemingly mutual' and that Bologna is 'seemingly more progressive', and she talks of her home context, and her position, in equally reserved terms ('this is not to suggest [...] by any means', 'perhaps even authority'). The doubt evident in her vignette points to the ways in which she continually seeks to query her own practice; an impulse which can be seen in line with understandings of criticality as operating with 'a tension between the need for firm enough ground to engage in political action while always simultaneously questioning the grounds on which such thoughts and action are located' (Pennycook 2012, 130). 
As she describes capitalising on her "'multicultural" credentials' in this vignette, Naomi stresses their incidental nature and reveals that she had little practical knowledge of community language schools in her home context. She makes explicit how her fieldwork experience was a catalyst for her to find out more about similar sites in Birmingham and in the UK. Her reconsideration of Birmingham is critical, in the sense that "to be critical requires an analytic move to self-position oneself as Other even in a market or field that might not necessarily construe or structurally position one as Other' (Luke 2004, 26). Similarly, she points out how her conversation with leaders of a Peruvian association caused her to recognise a contradiction in her understanding of, and quest for, 'traditional' and 'authentic' Bolognese food. As Friedman shows with the example of 'Italian' pasta and its forgotten Chinese origins, behind any fantasies of 'authentic cuisine' lie complex processes of globalization, cultural syncretism, and projections of local and contradictory meanings (1995, 69-90). The very idea of culinary authenticity can be considered 'spurious', and is usually an 'outsider' concern, related to tourism, gourmandise and exoticism (Appadurai 1986, 25). Indeed, the value of 'the authentic' more generally is tied up with the history of colonialism and the development of a particular, European model of personhood set up in contrast with essentialist depictions of 'primitive' Africa (Skeggs 2004). Concerning Italy specifically, the desirability of images of 'authentic Italy' and its cuisine today echo the function Italy performed in the era of the Grand Tour as a 'useful and necessary' point of reference for writers; a wild land of pleasure and adventure, and a contrast through which a sense of British identity has been developed (Pordzik 2005, 10). In acknowledging her own participation in this gastronomic exoticism in previous visits to Bologna, Naomi alludes to the ways in which the historic construction of Italy as England's 'exotic other' (Willman 2018; Pfister and Hertel 2008; Pordzik 2005) continues to shape perceptions today.

Sharing her thought process and personal reactions in this way, her vignette demonstrates in practical terms the potential for transcultural encounter to productively de-familiarize the familiar. In many ways, this is one of the most crucial processes of ethnographic research (Anderson 2018, 131-2), and indeed travel more generally, as de Certeau has described:

What does travel ultimately produce if it is not, by a sort of reversal, 'an exploration of the deserted places of my memory', the return to nearby exoticism by way of a detour through distant places, and the 'discovery' of relics and legends [...] in short, something like an 'uprooting in one's origins'? ([1984] 2013, 106-7)

In this respect, Naomi's vignette is suggestive of the ethnographic potential of all forms of travel, a point that is especially relevant given that, as English scholars without pre-existing familial ties to Italy, our initial approach to Italy was as a traveller; as a tourist. The insights that arise from her position and especially her culinary explorations - her critical revision of familiar contexts, the questioning of personal practice emphasise how our perspective on Italy is informed by a complex network of relationships and emotive responses, one of which is pleasure. 


\section{Discussion: Researching Italy in the UK}

In both vignettes, it is the material culture and practice of participants' everyday lives - wearing a hijab, eating Peruvian food, making and drinking Italian coffee - which provides a point of departure for personal reflections on wider social and political dynamics. While it has long been recognized that the everyday is the site where human behaviour is profoundly cultural (Mauss 1934), the critical potential of this line of inquiry is perhaps especially relevant from a Modern Languages perspective. Through our partially outsider position, as UK-based English scholars of Italy, the unremarkable becomes remarkable, and a site of critical inquiry. When we set the evident fascination with the bar environment in Georgia's vignette alongside Naomi's description of her culinary pursuits, our vignettes also serve to indicate how our engagement with these sites is influenced by a web of broader historical narratives and personal sentiment.

A sentiment evident in both vignettes, albeit in different ways, is an awareness and uncomfortableness with the ways Italian identity is explicitly racialized (Patriarca and Deplano 2018), and how we ourselves have been and continue to be implicated in the hegemonic role of whiteness in Italy (Giuliani and Lombardi-Diop 2013, 125). For example, the desire to 'pass' as a native Italian speaker is often for undergraduate learners represented and perceived as the ultimate goal, while both teachers and learners, in which we include ourselves, neglect to realise or articulate how linguistic competence is often secondary to the perceived racial identity of the speaker (Kubota and Lin 2009, 8).

In discussing our own reactions to the racialisation of Italian identity, our aim is not to imply that this is a phenomenon restricted to Italy. Indeed, to suggest that Italian identity appears, to white English scholars, as more overtly racialised is most likely symptomatic of the more implicit, systematic racism which Eddo-Lodge cites as obscuring race problems in the UK and effacing black British history (2017, 54-55). While the research discussed here took place largely before recent developments in the UK connected to the Brexit referendum, the current climate of more overt xenophobia and racist discourse illustrates the fallacy of earlier suggestions that such discourses or ideas were in any sense consigned to our own country's past (Emejulu 2016). Drawing on the contrasts between our research encounters and our lived experiences in urban UK environments, however, can be a point of departure for critically rethinking both contexts. In this sense, while we may not necessarily set out to conduct explicitly comparative studies between Italy and the UK, it is important to recognise that there is arguably an inherent comparatism to all UK-based Modern Languages research (Forsdick and Milne 2018).

This critical distance, or what in French studies has been described as le regard de l'etranger, can be the cause of discomfort both for the observer and the observed. As Kelly notes in relation to French cultural studies, there are two dimensions to this potentially threatening external gaze, the sense of judgement as well as the way those studying Italy outside of the peninsula may bring external frameworks of reference to bear on it (2014, 255). Potential hostility to this external judgement may be connected to nationalistic ideas that 
perceived 'visitors', or 'guests', from abroad are only allowed to express positive views of a country, while critique is reserved for the 'native-born' speaker. As white academics, we must not conflate our experiences with the hostility more commonly voiced in response to critiques expressed by those who have migrated, and in many cases even those born within that country but who are racialised as 'Other'. Our critiques undeniably operate in very different power dynamics, with such hostility, even if felt, rarely voiced.

Instead, we must acknowledge the authority granted to the UK academic system, and Anglophone academic writing more generally, ${ }^{2}$ and the consequent potential for our judgements to become more authoritative representations than those from within Italy or elsewhere. In particular, discomfort and the temptation to moderate our critiques is tied to a fear of being perceived as representing ourselves as superior or more 'advanced' Anglo-Saxons or Northern Europeans, particularly given the historical paradigm of Italy as England's 'exotic other'. There is a risk here of falling into the trap of what Fabian describes as 'the denial of coevalness', whereby the researcher places the researched in a time other than their own $(2014,31)$. This risk arises from Italy's own complex and ambivalent racialised history, which has seen its 'Mediterranean' character and supposed 'backwardness' often contrasted to that of supposedly more 'rational' Northern Europeans (Agnew 1997). It is also important to mention at this juncture Italy's 'internal subaltern question', with such a distinction historically made in the specific racialisation of Southern Italians. However, as Giuliani and Lombardi-Diop note, particularly due to the emigration histories of predominantly Southern Italians, outside of Italy this has reinforced 'una sorta di identificazione stereotipata tra l'italianità e la meridionalità/ruralità' [a kind of stereotypical identification of Italianness with Southern-ness/rurality] (2013, $31)$.

This conflation highlights the erasures which occur when attempting to define Italianness in generic ways which ignore local specificities. Undeniably, research based in a northern city such as Bologna and research conducted in Southern Italy, or concerned with Italian emigration, ${ }^{3}$ would consider processes of racialisation quite differently. This does not, however, prevent us from identifying within local contexts much wider patterns of discrimination and exclusion connected to racialised understandings of Italian national belonging (Lombardi-Diop and Romeo 2013, 29). Equally, recognising the power dynamics and racialised histories in which we operate as English researchers of Italy is tied up with a moral responsibility to represent the prejudices which others experience as a daily violence. This requires a conscious effort to refrain from generalising and simplistic interpretations which ignore or neglect the specificities of the histories and social and cultural forces at play, and which suggest it is merely a case of Italy needing to 'catch up'. While academic strategies for addressing these subjects, for example postcolonial theory and approaches, have arrived later to Italy, as Ponzanesi and Polizzi argue, there is a "special quality in this "delay" which has the potential to yield

\footnotetext{
${ }^{2}$ See for example Piller 2012 who highlights the dominance of English-language publications in multilingualism research.

${ }^{3}$ See for example Guglielmo and Salerno (2003) for an exploration of the historically ambiguous racial position of Italians in the US.
} 
new insights when applied to and developed from within the specific geopolitical situation of Italy $(2016,158$ 9). This reminds us that our own critiques should acknowledge those which have emerged forcefully from those currently or previously writing from within Italy. This includes the community of academics critically addressing the subjects of race, postcolonialism and migration, often in dialogue with academics based predominantly in the UK and the US (for example, in edited volumes such as Lombardi-Diop and Romeo 2013 and Bond, Faloppa and Bonsaver 2015).

Acknowledging the continued challenges to addressing these subjects from within the Italian academy (Derobertis 2014), we must also look to other spaces, such as literature, as one of the few public spaces from within which migrant-origin writers and writers of colour are able to voice experiences as migrant and/or racialised subjects (Parati 2005). Our own narratives of easily 'passing' as white Italians can be read in dialogue with Komla-Ebri's collection of Imbarazzismi (2013), in which several episodes make reference to a refusal to accept the possibility of a black speaker of Italian. Even more closely connected to our own vignettes are those of the writer Shirin Ramzanali Fazel, who recounts her own move from a northern Italian town to Birmingham (2017), which functions as a partial reverse of Naomi's own journey. ${ }^{4}$ While reflecting distinct trajectories of mobility and experiences of racialisation, evident parallels emerge in their reflections on the everyday multiculturalism of Birmingham, and its contrast to both a small Italian town and to the larger urban context of Bologna.

As Asad argues, 'In order for criticism to be responsible, it must always be addressed to someone who can contest it' $(1986,156)$. This is reflected in our own transcultural affiliations as Italian Studies scholars, which involve, if not 'a mimetic relationship' to Italian academia (Forsdick and Milne 2018, 181), then at the very least mutual respect and exchange. It is arguably this at least partial 'insider' status that allows us to move beyond Italophilia to see our role as active participants in the composition of the 'contested codes and representations' (Clifford 1986, 2) of Italian culture. A crucial part of such a practice is reflecting on the specific frameworks of reference we bring to bear in our representations of Italy, which, as highlighted in the bibliography of this article, are for us drawn predominantly from Anglophone traditions. Below we offer closing reflections on how we attempt to do so in the production of our textual representations of our research.

\section{Reflexivity in Writing and Representing}

Naomi: In my research in Bologna, I found the term 'multiculturalism' was often perceived negatively, and rejected as a model for the Italian experience in favour of the term 'intercultura', the term more commonly

\footnotetext{
${ }^{4}$ As part of the project, both researchers also worked closely with the writer on the development of a series of creative writing workshops in Birmingham, which allowed us to share these experiences and reflections through further dialogue. Following Brioni's examples of collaborations between migrant-origin writers and Italian-born academics or writers (2013), this dialogue could, however, be further developed in the future through a more formal collaborative output in order to explore these diverse historical perspectives and experiences in greater depth.
} 
used in continental European debates and policies (Guilherme and Dietz 2015, 5). The rejection of 'multiculturalism' was based partly on an understandable reluctance to accept an externally imposed model from a predominantly UK experience, but was also accompanied by the idea that multiculturalism in the UK was a failed experiment, based on the association of the term with the idea of segregated communities (Cecchini and Amelii 2014, 4). There is not space here to explore in depth the competing definitions of such terms, given also what Guilherme and Dietz describe as the 'culturally slippy' understandings of these terms as they are resignified across different national and local contexts $(2015,11)$. As a result, despite their widespread use they should not be treated as 'universal signifiers' $(2015,5)$, but rather as dependent on 'the multiple identities, the epistemological traditions and [...] the academic background of their users' $(2015,8$ 9).

For example, while I acknowledge critiques of the descriptive adequacy of the term 'multiculturalism', with the prefix 'multi' suggesting the idea of cultures as clearly bounded and countable entities (Welsch 1999, 19697), the lived experience of multiculturalism in the UK undeniably encompasses more fluid transcultural practices both within and across communities. At the same time, 'multiculturalism' is for me a less celebratory perspective which acknowledges more explicitly the histories of colonialism and unequal power structures involved, which apply equally if not in identical ways to Italy. Beyond more academic doubts, my own discomfort at this rejection of multiculturalism responded to personal affective attachments to the term, suggesting as the writer Zadie Smith explains that my own lived experience could be dismissed by others as merely 'evidence of a specific historical social experiment, now discredited' (2016). This more personal dimension highlights how in fieldwork the researchers themselves becomes the object of a counter-gaze (Puri 2016 , 40), forcing us to confront and make of our own cultural norms and values an object of study.

This example illustrates how an approach to research as a transcultural dialogue or exchange - a process of not just linguistic but also cultural translation - forces us to question the commonplaces, or topoi, of each culture (Santos 1999, 222). Rather than making a choice between imposing or abandoning my UK-influenced 'multicultural' framework, the admittedly challenging aim is to allow both perspectives to coexist in ways which acknowledge what Santos describes as the 'reciprocal incompleteness' of each $(1999,222)$. In particular, by explicitly recognising the unavoidably Anglo-Saxon framing of my research which results from my personal and academic trajectory, I seek to acknowledge the partiality of this perspective, with the aim following Clifford, not to be comprehensive or authoritative but to shed instead 'a strong, partial light' (1986, 21).

Georgia: My own research project, from which the questions this article raises first emerged, was aimed at drawing on personal narratives of individuals and focusing on the everyday transnationality of material culture as a means to counter methodological nationalism. Following Baldassar and Gabaccia's recognition, as scholars of Italian migration, that one of the sites in which the constructed nature of the nation-state is most 
visible is in the everyday lives of ordinary people $(2011,6)$, participant interviews were a key element of my exploration of what 'Italian' meant and means in England.

Transcribing the participant interviews I undertook during the course of my research I was struck on occasion by the awkward silence of my position. To be sure, inexperience played a role here, but so too did a reluctance to appear to be judgmental, or to be imposing my own beliefs in a way that risked playing into the power dynamics between Italy and England discussed above. Quite aside from the ethical implications of this deliberate omission on my part, when it came to writing up and presenting my research, I felt it was not fair and, returning to Asad's call for meaningful critique, irresponsible to use citations from participants I saw as problematic without having challenged them at the time. Though ethnographic practice traditionally places emphasis on participation as listening and observing, I believe it is worth considering further the insights we can gain from voicing our objections in certain contexts. I have found Sennett's ideal of the 'dialogic conversation' useful in this respect; the skill of disagreeing in a more productive form of exchange which prizes mutual recognition over sympathy or agreement $(2012,24)$. Equally, though, there is the need to translate the constructed and circumstantial nature of such conversations, the doubt and hesitancy of our indefinite positions, to the reader in our write-up. Presenting researcher subjectivity in qualitative research as an ethical issue, Abram points out that to try to erase oneself from the equation, to try to appear impartial is in itself a form of bias $(2014,38)$. As we have sought to demonstrate in this article, one way to address - without seeking to resolve - this question of partiality is to present the reader with a sense of the personal encounter at the heart of participant research, and indeed, to a certain extent, all research processes. Researcher vignettes, in all their awkward, clumsy rawness, can open up a more meaningful discussion by providing a clearly situated narrative for the reader to contemplate and even challenge.

\section{Conclusion}

Drawing on ethnographically influenced rhetorical forms, this article has illustrated the insights that can be gained through greater reflexivity on our individual positionalities as researchers, teachers and learners in Italian Studies. Rather than such reflections being framed as confessional attempts to exonerate ourselves, they have required us to take greater responsibility for the choices we make at all stages of our research. While the article has focused primarily on our research experiences, the intention is that our reflections may also contribute to ongoing discussions concerning the need for curriculum change within the discipline. The use of vignettes as research, for example, could easily be repurposed as a form of reflection and assessment for study abroad experiences, allowing students to develop greater criticality in relation to the everyday linguistic and cultural practices they encounter and participate in. This follows from Phipps and Gonzalez's earlier call to explore new approaches to Modern Languages which go beyond 'the reception and assimilation of a canon of texts' to instead engage with 'the living world of that language' $(2004,12)$. This is not to argue for the displacement of literary or historical study, but rather to suggest that insufficient analytical and critical 
attention is given to how Italian Studies inevitably entails emplaced and embodied encounters with the contemporary contexts of the associated countries and communities.

Being more open and reflexive about the positions from which we research and write, as well as acknowledging the uncertainties and gaps in our work, are strategies for displacing what Mullings describes as 'the indomitable authority of the author' (1999, 349), and instead opening up space for dialogue and contestation. The specific attention to our own national, gendered and racialised identities in these encounters illustrates how such reflexive accounts can provide critical tools to meaningfully consider our own positionalities. While actively acknowledging how we have both benefited from visual traits which have allowed us to easily 'pass' in Italy, such reflexive accounts are an opportunity to address more explicitly how the racialised nature of Italian national identity is intertwined with the hegemonic whiteness of the discipline itself. Attempts to broaden the student and staff body will not benefit from idealised representations which present the Italian language as a 'neutral' tool of communication or which remain silent over the racialised experiences students and staff encounter. ${ }^{5}$ However, a more reflexive approach to Italian Studies can contribute towards recognising and authorising the multiple historical and geographical positions from which we speak of, study and practice Italianness, both from within and beyond the Italian peninsula. In this sense, a transcultural Italian Studies must be aimed at disassociating the authority to define Italianness from a specific place, institution or people. Understanding our own transcultural practices and identities as teachers and researchers with affinities which go beyond a distanced 'academic' interest, also means abandoning ideals of both objective outsider and privileged insider knowledge, and instead acknowledging and exploring the ways in which we all shift, at times uneasily, between such positions (Mullings 1999).

\section{Acknowledgements}

Both authors' research was financed by the Arts and Humanities Research Council (AHRC), as part of the project 'Transnationalizing Modern Languages: Mobility, Identity and Translation in Modern Italian Cultures' (AH/L007061/1). Georgia's subsequent postdoctoral research, from which this article also draws, was supported by the AHRC Open World Research Initiative 'Cross-Language Dynamics: Reshaping Community' consortium (AH/N004647/1). Georgia would like to thank the organizers and attendees of the University of Warwick's Ethnography Circle for sharing their thoughts on vignettes. Naomi would like to thank the individuals and groups who made her research in Bologna possible by welcoming her into their community spaces and generously giving their time to talk to her. We would also like to thank the other members of the 'Transnationalizing Modern Languages' team, with the reflections developed in this article informed by wider conversations across the team, and with other researchers and writers who collaborated with the project.

\section{Notes on Contributors}

\footnotetext{
${ }^{5}$ See, for example, recent accounts from the US which highlight the continued silences on racialised experiences during undergraduate study abroad in Italy (Philip 2018) and the prevailing blindness to the whiteness of the discipline (Parker 2018).
} 
Dr Georgia Wall has recently completed an Early Career Fellowship at the Institute of Advanced Study, University of Warwick. Previously she was a Visiting Fellow at the Institute of Modern Languages Research (School of Advanced Study, University of London) as part of the AHRC Open World Research Initiative 'Cross-Language Dynamics: Reshaping Community' consortium (2018). She was a doctoral researcher as part of the AHRC 'Transnationalizing Modern Languages' project (2014-2018), where she focused on food culture and the use of ethnographic approaches in Italian Studies.

Dr Naomi Wells is a Postdoctoral Research Associate in Translingual Communities and Digital Humanities at the Institute of Modern Languages Research (School of Advanced Study, University of London) on the AHRCfunded Open World Research Initiative project 'Cross-Language Dynamics: Reshaping Community'. She was previously a Research Fellow on the AHRC-funded 'Transnationalizing Modern Languages' project, where her work and forthcoming publication focus on the linguistic and cultural practices of migrant and intercultural associations in the city of Bologna, Italy.

\section{References}

Abram, S. 2014. “'Bias Binding”: Re-calling Creativity in Qualitative Research.' In The Craft of Knowledge, edited by Carol Smart, Jenny Hockey and Allison James, 21-38. Basingstoke: Palgrave Macmillan.

Agnew, J. 1997. 'The Myth of Backward Italy in Modern Europe'. In Revisioning Italy: National Identity and Global Culture, edited by Beverly Allen and Mary Russo, 23-42. Minneapolis, MN: University of Minnesota Press.

Anderson, B. R. O’G. 2018. A Life beyond Boundaries. London: Verso.

Appadurai, A. 1986. 'On Culinary Authenticity'. Anthropology Today 2 (4): 24-25.

Asad, T. 1986. 'The Concept of Cultural Translation in British Social Anthropology.' In Writing Culture: The Poetics and Politics of Ethnography, edited by James Clifford and George E. Marcus, 141-64. Berkeley, Los Angeles, London: California University Press.

Back, L. 1996. New Ethnicities and Urban Culture: Racisms and Multiculture in Young Lives. Race and Representation 2. London: UCL Press.

Bakhtin, M. M. 1981. The Dialogic Imagination: Four Essays. Translated by Michael Holquist. University of Texas Press Slavic Series, no. 1. Austin: University of Texas Press.

Baldassar, L., and D. R. Gabaccia, eds. 2011. Intimacy and Italian Migration: Gender and Domestic Lives in a Mobile World. 1st ed. Critical Studies in Italian America. New York: Fordham University Press.

Bartoloni, P., and F. Ricatti. 2017. 'David Must Fall! Decentring the Renaissance in Contemporary and Transcultural Italian Studies.' Italian Studies 72 (4): 361-79. https://doi.org/10.1080/00751634.2017.1370787.

Bhabha, H.K. 2004. The Location of Culture. London: Routledge Classics.

Bond, E. 2014. 'Towards a Trans-national Turn in Italian Studies?' Italian Studies 69 (3): 415-24.

Bond, E., G. Bonsaver, and F. Faloppa, eds. 2015. Destination Italy: Representing Migration in Contemporary Media and Narrative. Bern: Peter Lang.

Brioni, S. 2015. The Somali within: Language, Race and Belonging in Minor Italian Literature. Cambridge: Legenda, Modern Humanities Research Association and Maney Publishing.

Brioni, S. 2013. 'Pratiche "meticce": Narrare il colonialismo italiano "a più mani"'. In Postcoloniale italiano: Tra letteratura e storia, edited by Franca Sinopoli, 89-119. Aprila: Novalogos.

Brioni, C. and S. Brioni. 2018. 'Interdisciplinarity and Collaborative Writing in the Humanities: Lara Saint Paul and the Performativity of Race', Interdisciplinary Italy, 22 May, accessed 15 April 2019, 
www.interdisciplinaryitaly.org/interdisciplinarity-collaborative-writing-humanities-lara-saint-paulperformativity-race/

British Academy. 2009. 'Languages Matters', British Academy, 30 June, accessed 15 April 2019, https://www.thebritishacademy.ac.uk/sites/default/files/LanguageMatters2_0.pdf

Burdett, C. 2018. 'Moving from a National to a Transnational Curriculum.' Languages, Society \& Policy. 18 July. http://www.meits.org/policy-papers/paper/moving-from-a-national-to-a-transnationalcurriculum-the-case-of-italian-st

Castillo, D.A., and S. Puri. 2016. 'Introduction: Conjectures on Undisciplined Research.' In Theorizing Fieldwork in the Humanities, edited by Debra A. Castillo and Shalini Puri, 1-27. New York: Palgrave Macmillan.

Cecchini, R., and F. Amelii. 2014. 'Investire Nella Diversità. Una Fotografia Della Rete Dei Centri Interculturali Dell'Emilia-Romagna.' Regione Emilia-Romagna (Assessorato Politiche Sociali).

Certeau, M. de. 2013. The Practice of Everyday Life. 1. Berkeley, Calif.: Univ. of California Press.

Clifford, J. 1986. 'Introduction: Partial Truths.' In Writing Culture: The Poetics and Politics of Ethnography, edited by James Clifford and George E. Marcus, 1-26. Berkeley, Los Angeles, London: California University Press.

Cook, I. et al. 2005. 'Positionality/Situated Knowledge'. In Cultural Geography: A Critical Dictionary of Key Concepts, edited by D. Sibley, P. Jackson, D. Atkinson and N. Washbourne. London; New York: I.B. Tauris, 16-25.

Copland, F., A. Creese, F. Rock, and S. Shaw. 2015. Linguistic Ethnography: Collecting, Analysing and Presenting Data. Los Angeles: SAGE.

Creese, A., A. Blackledge, A. Bhatt, C. Jonsson, K. Juffermans, J. Li, P. Martin, A. Muhonen, and J. K. Takhi. 2015. 'Researching Bilingual and Multilingual Education Multilingually: A Linguistic Ethnographic Approach.' In The Handbook of Bilingual and Multilingual Education, edited by Wayne E. Wright, Sovicheth Boun, and Ofelia García, 127-44. Chichester, UK: John Wiley \& Sons, Ltd. https://doi.org/10.1002/9781118533406.ch8.

Creese, A. J. K. Takhi and A. Blackledge. 2016. 'Reflexivity in team ethnography. Using researcher vignettes.' In Researching Multilingualism: Critical and ethnographic perspectives, edited by M. Martin-Jones and D. Martin, 203-214. Oxford; New York: Routledge, 2016.

Derobertis, R. 2014. 'Da dove facciamo il postcoloniale?'. Postcolonialitalia, (accessed 15 April 2019, http://www.postcolonialitalia.it/index.php?option $=$ com_content\&view $=$ article\&id=56:da-dovefacciamo-il-postcoloniale \&catid=27:interventi\&Itemid=101\&lang=it.

Eddo-Lodge, R. 2017. Why I'm No Longer Talking To White People About Race. London: Bloomsbury.

Emejulu, A. 2016. 'On the Hideous Whiteness Of Brexit: "Let Us Be Honest about Our Past and Our Present If We Truly Seek to Dismantle White Supremacy"' (blog). Verso Books, accessed 15 April 2019, https://www.versobooks.com/blogs/2733-on-the-hideous-whiteness-of-brexit-let-us-be-honest-aboutour-past-and-our-present-if-we-truly-seek-to-dismantle-white-supremacy.

Fabian, J. 2014. Time and the Other: How Anthropology Makes Its Object. New York: Columbia University Press.

Faloppa, F. 2011. Razzisti a Parole (per Tacer Dei Fatti). 1. ed. Il Nocciolo 64. Rome: Laterza.

Forsdick, C., and A. L. Milne. 2018. 'Le Regard de l'étranger? France as 'Elsewhere'. Un Échange à Partir de Six Question.' Fixxion: Revue Critique de Fixxion Française Contemporaine, no. 18: 179-90.

Freidman, J. 1995. 'Global System, Globalization and the Parameters of Modernity'. In Global Modernities, edited by Mike Featherstone, Scott Lash and Roland Robertson, 69-90. London: Sage.

Gellner, D. N. 2012. 'Uncomfortable Antinomies. Going Beyond Methodological Nationalism in Social and Cultural Anthropology'. In Beyond Methodological Nationalism: Research Methodologies for 
Cross-Border Studies, edited by A. Amelina, D. D. Nergiz, T. Faist and N. Glick Schiller. Oxford; New York: Routledge.

Giuliani, G., and C. Lombardi-Diop. 2013. Bianco e Nero: Storia Dell'identità Razziale Degli Italiani. 1. ed. Le Monnier università. Quaderni Di Storia. Florence: Le Monnier università.

Guglielmo, J. and S. Salerno. 2003. Are Italians white? How race is made in America. New York: Routledge.

Guilherme, M. and G. Dietz. 2015. 'Difference in Diversity: Multiple Perspectives on Multicultural, Intercultural, and Transcultural Conceptual Complexities'. Journal of Multicultural Discourses 10 (1):1-21. https://doi.org/10.1080/17447143.2015.1015539

Heller, M. 2009. 'Doing Ethnography.' In The Blackwell Guide to Research Methods in Bilingualism and Multilingualism, edited by Li Wei and Melissa G. Moyer, 249-62. Oxford, UK: Blackwell Publishing Ltd. https://doi.org/10.1002/9781444301120.ch14.

Holmes, P., R. Fay, J. Andrews, and M. Attia. 2013. 'Researching Multilingually: New Theoretical and Methodological Directions: Researching Multilingually.' International Journal of Applied Linguistics 23 (3): 285-99. https://doi.org/10.1111/ijal.12038.

Kelly, M. 2014. 'Le Regard de l'étranger : What French Cultural Studies Brings to French Cultural History.' Edited by Nicholas Hewitt. French Cultural Studies 25 (3-4): 253-61. https://doi.org/10.1177/0957155814543894.

Komla-Ebri, Kossi. 2013. Imbarazzismi. Prato: Edizioni SUI.

Kubota, R., and A. M. Y. Lin. 2009. 'Race, Culture, and Identities in Second Language Education.' In Race, Culture, and Identities in Second Language Education: Exploring Critically Engaged Practice, edited by Ryuko Kubota and Angel M. Y. Lin, 1-23. New York: Routledge.

Lombardi-Diop, C., and C. Romeo, eds. 2013. Postcolonial Italy: Challenging National Homogeneity. First Palgrave Macmillan paperback edition. Italian and Italian American Studies. New York, NY: Palgrave Macmillan.

Luke, A. 2004. 'Two takes on the critical'. In Critical Pedagogies and Language Learning, 21-29, edited by B. Norton and K. Toohey. Cambridge: Cambridge University Press.

Mauss, M. 1936. 'Les techniques du corps.' Journal de Psychologie 32 (3-4): 271-293. Published in English in 1973. 'Techniques of the Body', trans. Ben Brewster. Economy and Society 2 (1):70-88.

Miller, D. 2008. The Comfort of Things. Cambridge, UK; Malden, MA: Polity.

Mullings, B. 1999. "Insider or Outsider, Both or Neither: Some Dilemmas of Interviewing in a CrossCultural Setting." Geoforum 30 (4): 337-50. https://doi.org/10.1016/S0016-7185(99)00025-1.

Patriarca, Silvana, and Valeria Deplano. 2018. 'Nation, 'Race”, and Racisms in Twentieth-Century Italy.' Modern Italy 23 (4): 349-53. https://doi.org/10.1017/mit.2018.38.

Parati, G. 2005. Migration Italy: The Art of Talking Back in a Destination Culture. Toronto; Buffalo: University of Toronto Press.

Parker, D. 2018. 'Race and Foreign Language.' Inside Higher Ed, June 21, accessed 15 April 2019, https://www.insidehighered.com/views/2018/06/21/paucity-asians-and-other-minorities-teachingand-studying-italian-and-other-foreign.

Pennycook, A. 2012. Unexpected Places: Language and Mobility. Critical Language and Literacy Studies, v. 15. Bristol; Buffalo: Multilingual Matters.

Pfister, M. and R. Hertel. (eds.) 2008. Performing National Identity: Anglo-Italian Cultural Transactions. New York: Rodopi,

Phillip, N. 2018. 'My Very Personal Taste of Racism Abroad.' The New York Times, October 23, accessed 15 April 2019, https://www.nytimes.com/2018/10/23/travel/racism-travel-italy-study-abroad.html. 
Phipps, A. M., and M. Gonzalez. 2004. Modern Languages: Learning and Teaching in an Intercultural Field. Teaching \& Learning the Humanities in Higher Education. London; Thousand Oaks, Calif: Sage.

Piller, I. 2016. "Monolingual Ways of Seeing Multilingualism.” Journal of Multicultural Discourses 11 (1): 25-33. https://doi.org/10.1080/17447143.2015.1102921.

Polezzi, L. 2013. 'Disrupting Europe: Polylingual Models and Common Selves', European Institute for Progressive Cultural Policies, accessed 15 April 2019, http://eipcp.net/transversal/0613/polezzi/en

Ponzanesi, S., and G. Polizzi. 2016. 'Does Italy need Postcolonial Theory? Intersections in Italian Postcolonial Studies'. English Literature 3: 145-161.

https://edizionicafoscari.unive.it/media/pdf/article/english-literature/2016/0numeromonografico/does-italy-need-postcolonial-theory/art-10.14277-2420-823X-EL-3-16-8.pdf

Pordzik, R. 2005. The Wonder of Travel: Fiction, Tourism and the Social Construction of the Nostalgic. Anglistische Forschungen, Bd. 344. Heidelberg: Winter.

Pratt, M. 1991. 'Arts of the Contact Zone'. Profession, 33-40.

Puri, S. 2016. 'Finding the Field: Notes on Caribbean Cultural Criticism, Area Studies, and the Forms of Engagement.' In Theorizing Fieldwork in the Humanities, edited by Debra A. Castillo and Shalini Puri, 29-50. New York: Palgrave Macmillan.

Ramzanali Fazel, S. 2013. Lontano da Mogadiscio/Far from Mogadishu. Milan: Laurana.

Rosaldo, R. 1993. Culture \& Truth: The Remaking of Social Analysis: With a New Introduction. Boston: Beacon Press.

Santos, B. de S. 1999. 'Towards a Multicultural Conception of Human Rights.' In Spaces of Culture: City, Nation, World, edited by M. Featherstone and S. Lash, 214-29. London: SAGE Publications Ltd.

Sennett, R. 2012. Together: The Rituals, Pleasures and Politics of Cooperation. London: Allen Lane.

Sennett, R., and J. Cobb. 1993. The Hidden Injuries of Class. New York: Norton.

Skeggs, B. 2004. Class, Self, Culture. London: Routledge.

Smith, Z. 2016. 'On Optimism and Despair.' The New York Review of Books, December 22, accessed 15 April 2019, https://www.nybooks.com/articles/2016/12/22/on-optimism-and-despair/.

Transnationalizing Modern Languages. Transnationalizing Modern Languages: Mobility, Identity and Translation in Modern Italian Cultures, accessed 10 May 2018, www.transnationalmodernlanguages.ac.uk.

Welsch, W. 1999. "Transculturality: The Puzzling Form of Cultures Today." In Spaces of Culture: City, Nation, World, edited by M. Featherstone and S. Lash, 195-213. London: SAGE Publications Ltd.

Willman, K. 2018. 'Contemporary British Travel Writing on Italy and British Broadsheets: Tobias Jones, John Hooper and Tim Parks. Modern Languages Open 1: 8. http://doi.org/10.3828/mlo.v0i0.159

Wimmer, A., and N. Glick Schiller. 2002. 'Methodological Nationalism and beyond: Nation-State Building, Migration and the Social Sciences.' Global Networks 2 (4): 301-34. https://doi.org/10.1111/14710374.00043 .

Woodward, S. 2016. 'Object Interviews, Material Imaginings and "Unsettling" Methods: Interdisciplinary Approaches to Understanding Materials and Material Culture.' Qualitative Research 16 (4): 359-74. https://doi.org/10.1177/1468794115589647.

\section{Italian Summary}


Questo articolo considera alcune delle questioni etiche, epistemologiche e problemi pratici che sorgono spontanei qualora si fa ricerca in contesti di migrazione italiana. La nostra prospettiva è alimentata da teorie e pratiche etnografiche. Utilizzando le nostre rispettive esperienze di ricerca in Italia e nel Regno Unito scaturite dalla partecipazione al progetto 'Transnationalizing Modern Languages', esaminiamo come il nostro posizionamento di ricercatrici bianche e inglesi nell'ambito dell'italianistica abbia sollevato questioni pertinenti di potere, privilegio e voce. A dare corpo all'articolo contribuisce l'uso dello strumento di ricerca 'vignette' nel quale la personale esperienza etnografica gioca un ruolo primario nell'analizzare la realtà. Attraverso l'analisi di alcune delle 'tensioni irrisolvibili' della nostra ricerca, ci impegniamo a rispondere alla necessità di trovare nuovi modi di studiare e scrivere cultura. 